\title{
The RNA binding protein HuR does not interact directly with HIV-1 reverse transcriptase and does not affect reverse transcription in vitro
}

\author{
Jinwoo Ahn', In-Ja L Byeon', Sanjeewa Dharmasena², Kelly Huber², Jason Concel' ${ }^{1}$, Angela M Gronenborn*1 and \\ Nicolas Sluis-Cremer ${ }^{* 2}$
}

\begin{abstract}
Background: Lemay et al recently reported that the RNA binding protein HuR directly interacts with the ribonuclease $\mathrm{H}$ (RNase H) domain of HIV-1 reverse transcriptase (RT) and influences the efficiency of viral reverse transcription (Lemay et al., 2008, Retrovirology 5:47). HuR is a member of the embryonic lethal abnormal vision protein family and contains 3 RNA recognition motifs (RRMs) that bind AU-rich elements (AREs). To define the structural determinants of the HuR-RT interaction and to elucidate the mechanism(s) by which HuR influences HIV-1 reverse transcription activity in vitro, we cloned and purified full-length HuR as well as three additional protein constructs that contained the Nterminal and internal RRMs, the internal and C-terminal RRMs, or the C-terminal RRM only.

Results: All four HuR proteins were purified and characterized by biophysical methods. They are well structured and exist as monomers in solution. No direct protein-protein interaction between HuR and HIV-1 RT was detected using NMR titrations with ${ }^{15} \mathrm{~N}$ labeled HuR variants or the ${ }^{15} \mathrm{~N}$ labeled RNase H domain of HIV-1 RT. Furthermore, HuR did not significantly affect the kinetics of HIV-1 reverse transcription in vitro, even on RNA templates that contain AREs.
\end{abstract}

Conclusions: Our results suggest that HuR does not impact HIV-1 replication through a direct protein-protein interaction with the viral RT.

\section{Background}

Reverse transcription of the viral single-stranded $(+)$ RNA genome into double-stranded DNA is a critical step in the HIV-1 life-cycle. Although the viral proteins nucleocapsid, matrix, integrase, tat, nef and vif may participate in the regulation and/or efficiency of reverse transcription [1-6], synthesis of the nascent HIV-1 DNA is entirely carried-out by the DNA polymerase and ribonuclease $\mathrm{H}$ (RNase H) activities of HIV-1 reverse transcriptase (RT). HIV-1 RT is an asymmetric heterodimer composed of 66 $\mathrm{kDa}$ (p66) and $51 \mathrm{kDa}$ (p51) subunits [7]. The p66 subunit can be subdivided into DNA polymerase, connection and

*Correspondence: amg100@pitt.edu

, nps2@pitt.edu

1 Department of Structural Biology, Division of Infectious Diseases, University of Pittsburgh School of Medicine, Pittsburgh, PA 15261, USA

2 Department of Medicine, Division of Infectious Diseases, University of Pittsburgh School of Medicine, Pittsburgh, PA 15261, USA

Full list of author information is available at the end of the article
RNase $\mathrm{H}$ domains. The $\mathrm{p} 51$ subunit is derived from $\mathrm{p} 66$ by HIV-1 protease cleavage of the C-terminal RNase $\mathrm{H}$ domain. The p66/p51 HIV-1 RT heterodimer contains one DNA polymerization active site and one RNase $\mathrm{H}$ active site, which both reside in the p66 subunit in spatially distinct regions [7].

Recent studies suggest that host cell proteins may also play an important role in the timing and efficiency of HIV-1 reverse transcription [8-12]. For example, a genome-wide siRNA analysis conducted by König et al identified $\sim 30$ host cell factors that directly influence either the initiation or kinetics of reverse transcription [8]. However, by its nature, this study did not distinguish direct physical interactions from indirect effects between these host cell factors and any of the viral proteins present in the reverse transcription complex in infected cells. By contrast, in other reports, several host cell proteins, such as HuR, AKAP149 and TRIM37 have all been impli- 
cated in direct contacts with HIV-1 RT that impact viral replication $[9,10,12]$. Validation and comprehensive analysis of these putative RT-host protein interactions are important for a thorough understanding of viral replication and for drug discovery efforts that target HIV-host protein interactions.

The present study was devised to structurally characterize the interaction between HuR and HIV-1 RT that was recently described by Lemay et al [9], who identified HuR and HIV-1 RT association in a yeast two-hybrid screen and confirmed the interaction by a homogenous time-resolved fluorescence binding assay. The authors mapped the HIV-1 RT-HuR binding sites to the RNase $\mathrm{H}$ domain of RT and to the C-terminus of HuR (see Fig. 1). Importantly, siRNA knockdown of $\mathrm{HuR}$ expression in HeLa P4.2 cells was reported to greatly impair both the early and late steps of viral reverse transcription. To further define the structural determinants of the HIV-1 RT$\mathrm{HuR}$ interaction at the atomic level and to elucidate the mechanism(s) by which HuR influences HIV-1 reverse transcription activity in vitro, we prepared and characterized four $\mathrm{HuR}$ protein constructs and investigated their RT interaction by biophysical methods. We did not find any evidence for a direct interaction between HIV-1 RT and HuR by NMR chemical shift mapping in the ${ }^{1} \mathrm{H},{ }^{15} \mathrm{~N}$ heteronuclear single quantum coherence (HSQC) spectra of ${ }^{15} \mathrm{~N}$-labeled HuR or ${ }^{15} \mathrm{~N}$-labeled HIV-1 RT RNase $\mathrm{H}$ upon titration with unlabeled RT or HuR. Furthermore, HuR did not affect the kinetics of HIV-1 reverse transcription in vitro. Taken together, our results suggest that $\mathrm{HuR}$ does not impact HIV-1 replication through a direct interaction with the viral RT.

\section{Results}

\section{Purification and characterization of HuR}

HuR belongs to the Hu family of mRNA stabilizing proteins that interact with AU-rich elements (ARE), sharing

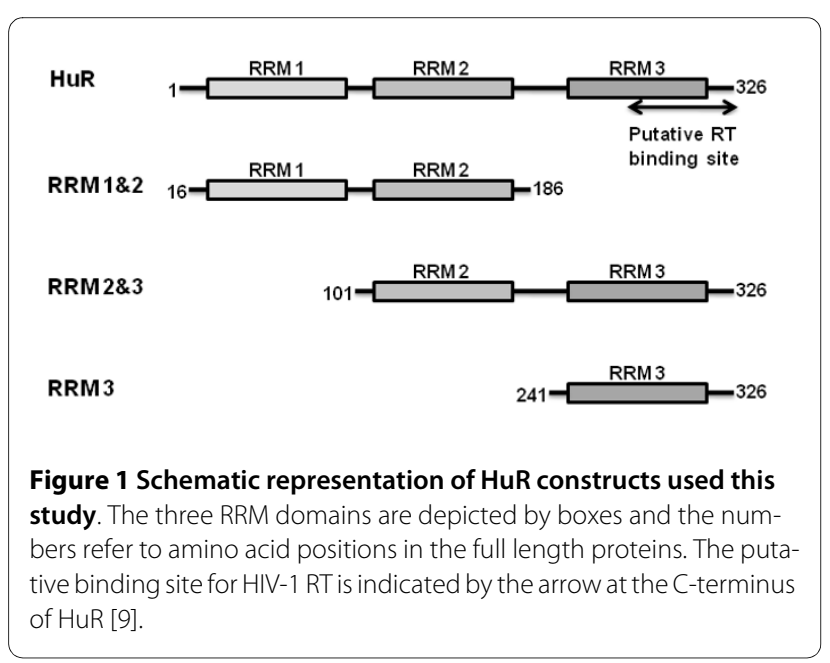

significant sequence similarity with the Drosophila RNAbinding protein ELAV (embryonic lethal abnormal vision) [13]. The 326 amino acid protein contains three RNA recognition motifs ( $\mathrm{R} R \mathrm{Ms}$ ), two in the $\mathrm{N}$-terminal half and a third at the $\mathrm{C}$-terminus, separated by a basic $\sim 60$ residue linker region (Fig. 1). HuR recognizes a core element of 27 nucleotides in the RNA that contain AUUUA, AUUUUA and AUUUUUA motifs [14-16]. RRM 1 and RRM 2 contribute most of the binding energy in HuR-ARE complex formation [14], while RRM 3 may be responsible for cooperative assembly of HuR oligomers on RNA [17]. In addition, RRM 3 of $\mathrm{HuR}$ was reported by Lemay et al to directly interact with the RNase H domain of HIV-1 RT [9].

To further define the structural determinants of the HuR-RT interaction and to elucidate the mechanism(s) by which $\mathrm{HuR}$ influences $\mathrm{HIV}-1$ reverse transcription activity in vitro, we prepared HuR N-terminal fusion proteins with glutathione S-transferase (GST) and NusA. The GST-HuR fusion protein was unstable after purification and underwent substantial degradation at room temperature (Fig. 2A). In contrast, the NusA-HuR fusion was stable and was used in the NMR and HIV-1 RT DNA synthesis reactions described below. We also cloned the RRM 1\&2, RRM 2\&3, or RRM 3 domains of HuR as Nterminal fusion proteins with NusA (Fig. 1). These domain constructs exhibited sufficient stability after cleavage by TEV protease and removal of the NusA tag for structural characterization by NMR.

The quaternary states of NusA-HuR and NusA-RRM 3 were assessed by multi-angle light scattering (Fig. 2B). Both proteins were found to exist as monomers in solution and the molecular masses of NusA-HuR and NusARRM 3 were determined as 82.2 and $68.9 \mathrm{kDa}$, respectively. These values are within $\pm 15 \%$ of the predicted masses of $99 \mathrm{kDa}$ for NusA-HuR and $73 \mathrm{kDa}$ for NusARRM 3. We did not find any evidence for HuR dimer formation, in contrast to a previous report that suggested HuR homodimerization prior to RNA binding [18]. Furthermore, we show that NusA-HuR binds a synthetic RNA template that contains AREs (Fig. 2C), indicating that the fusion does not interfere with the RNA binding activity of HuR.

\section{Probing the interaction between HIV-1 RT and HuR by NMR}

We used ${ }^{1} \mathrm{H},{ }^{15} \mathrm{~N}-\mathrm{HSQC}$ NMR spectroscopy $[19,20]$ to probe whether a direct interaction between HIV-1 RT and HuR could be identified in vitro. Several different proteins were investigated: (i) the ${ }^{15} \mathrm{~N}$-labeled RRM 3 domain of HuR was titrated with full-length HIV-1 RT (Fig. 3A); (ii) the ${ }^{15} \mathrm{~N}$-labeled RRM $1 \& 2$ of $\mathrm{HuR}$ was titrated with the RNase H domain of HIV-1 RT (Fig. 3B); and (iii) the ${ }^{15} \mathrm{~N}$-labeled RNase $\mathrm{H}$ domain of HIV-1 RT was titrated with NusA-HuR (Fig. 3C). All three ${ }^{15} \mathrm{~N}$ - 
A
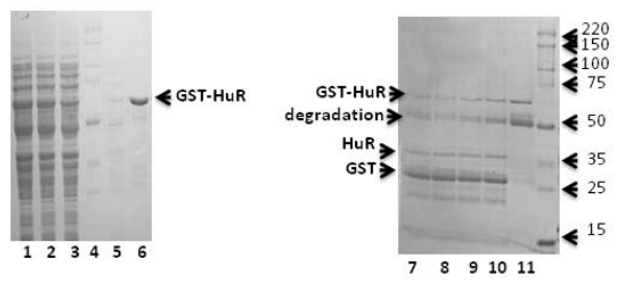

B

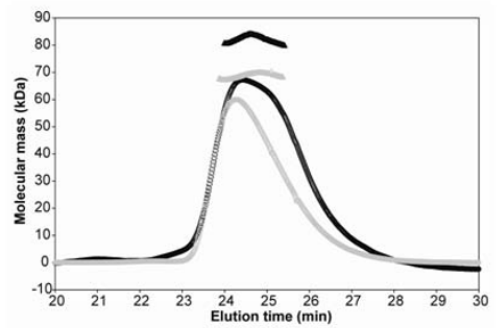

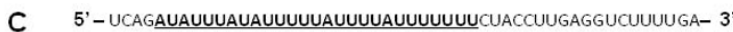

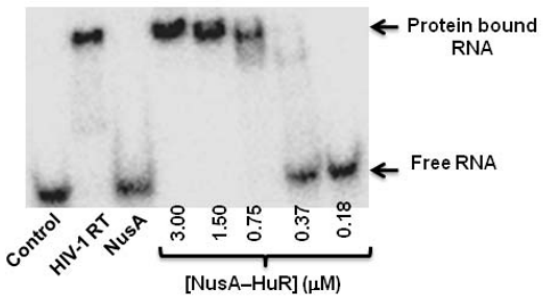

Figure 2 Purification and biophysical characterization of GSTand NusA-HuR. (A) Analysis of the expression and purification of GSTHuR by SDS PAGE. Lanes 1 and 2 illustrate total protein and total soluble protein after E. coli cell lysis, respectively, lane 3 shows the flowthrough fraction of the glutathione sepharose column, lane 4 contains molecular weight markers and lane 5 is the eluate during the column wash. Purified GST-HuR eluted from the glutathione sepharose column with $20 \mathrm{mM}$ glutathione is shown in lane 6 and lanes 7-10 contain purified GST-HuR that was incubated with $0.15,0.1,0.05$ and 0.03 units of thrombin, respectively, for $1 \mathrm{~h}$ at room temperature. Lane 11 contains purified GST-HuR incubated for $1 \mathrm{~h}$ in buffer at room temperature in the absence of thrombin. (B) Size-exclusion multi-angle light scattering analysis of NusA-HuR (black) and NusA-RRM 3 (grey). The elution profiles (circles) and the predicted molecular masses obtained from the light-scattering measurements (triangles) are shown. Both proteins were found to exist $>90 \%$ as monomers in solution. (C) Gel-shift assay of HuR binding to single-stranded RNA. The sequence of the RNA used in this experiment is shown above the autoradiograph. The ARE sequence is highlighted and underlined. HIV-1 RT and NusA were included as controls in this experiment.

labeled proteins exhibited well-dispersed ${ }^{1} \mathrm{H},{ }^{15} \mathrm{~N}-\mathrm{HSQC}$ spectra, indicative of well-folded, stable structures. No changes in their ${ }^{1} \mathrm{H},{ }^{15} \mathrm{~N}-\mathrm{HSQC}$ spectra were observed upon titration with the unlabelled binding partners up to a two-fold molar excess. It, therefore, is highly unlikely that direct protein-protein contacts are present for any of the above protein pairs.

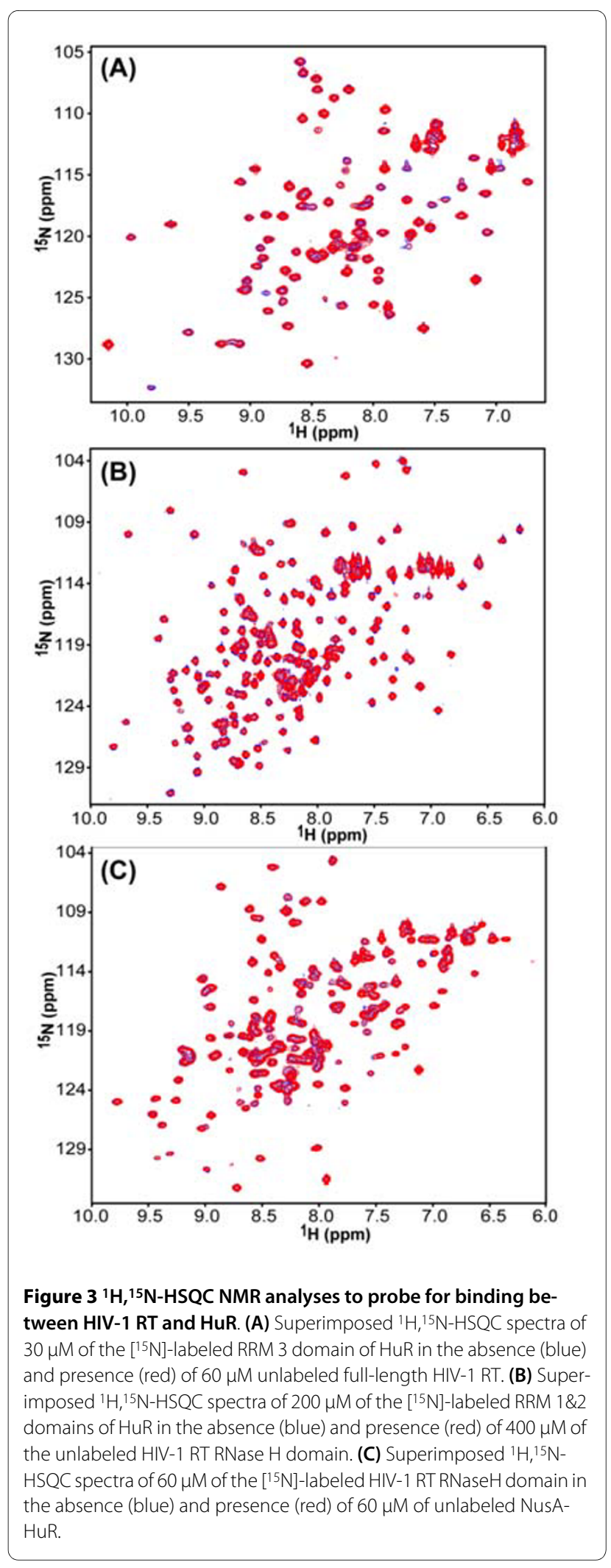




\section{HuR does not impact the DNA synthesis efficiency of HIV-1 $R T$ in vitro}

Although our NMR data exclude the presence of direct physical protein-protein contacts between HIV-1 RT and $\mathrm{HuR}$, indirect effects from one protein to the other may occur, possibly mediated by RNA. To investigate this possibility, we carried out HIV-1 RT DNA synthesis reactions using two different template/primer (T/P) substrates. In the first, we used a long heteropolymeric RNA template, corresponding to the HIV-1 sequence used for (-) strong stop DNA synthesis, that was primed with an 18 nucleotide DNA primer. In this assay, 173nucleotide incorporation events are needed to produce the full-length DNA product, allowing multiple dNTP additions [21,22]. Importantly, this template does not contain AREs that would interfere with HuR binding to the RNA (data not shown). DNA synthesis reactions carried out with this $\mathrm{T} / \mathrm{P}$ in the presence of NusA-HuR, NusA-RRM 3 or NusA-RRM $2 \& 3$ were not significantly different from the control reaction in the presence of NusA only (Fig. 4A). Next, we investigated HIV-1 RT DNA synthesis on a $\mathrm{T} / \mathrm{P}$ substrate that contains AREs (Fig. 4B). Gel-shift assays confirmed that $\mathrm{HuR}$ bound to this $\mathrm{T} / \mathrm{P}$ (Fig. 4B). However, the binding of HuR to the RNA did not appear to significantly affect the efficiency of $\mathrm{HIV}-1 \mathrm{RT}$ reverse transcription on this $\mathrm{T} / \mathrm{P}$ substrate either (Fig. 4B).

\section{Discussion}

Lemay et al identified HuR as a binding partner for HIV-1 $\mathrm{RT}$ in a yeast two-hybrid screen of a random primed cDNA library derived from CEMC7 lymphocytes, and a physical interaction in vitro was proposed based on timeresolved fluorescence data [9]. In the reported fluorescence experiment, serial dilutions of GST-HuR (or GST alone) were incubated with a constant amount of C-terminal hexahistidine tagged HIV-1 RT for 24 hours at $4^{\circ} \mathrm{C}$. Subsequently, the interaction was probed by fluorescence energy transfer using anti-GST antibodies conjugated with the donor $\mathrm{TBPEu}^{3+}$ and anti-hexahistidine antibodies conjugated with the acceptor XL665. In our experiments, we discovered that the GST-HuR fusion protein is not stable in solution for extended periods and is subject to degradation, casting doubt on the validity of the above interpretation. Indeed, Lemay et al. may have looked at an interaction, most-likely a non-specific one, between HIV-1 RT and a degraded/unfolded form of GST-HuR. In this regard it is well known that marginally stable proteins are prone to aggregation, a non-specific protein-protein interaction. It should be noted, however, that Lemay et al cloned $\mathrm{HuR}$ into the pGEX-4T-1 vector whereas we cloned it into the pGEX-2T vector. The resultant fusion proteins are identical in amino acid sequence except that the Lemay et al construct contains an additional proline

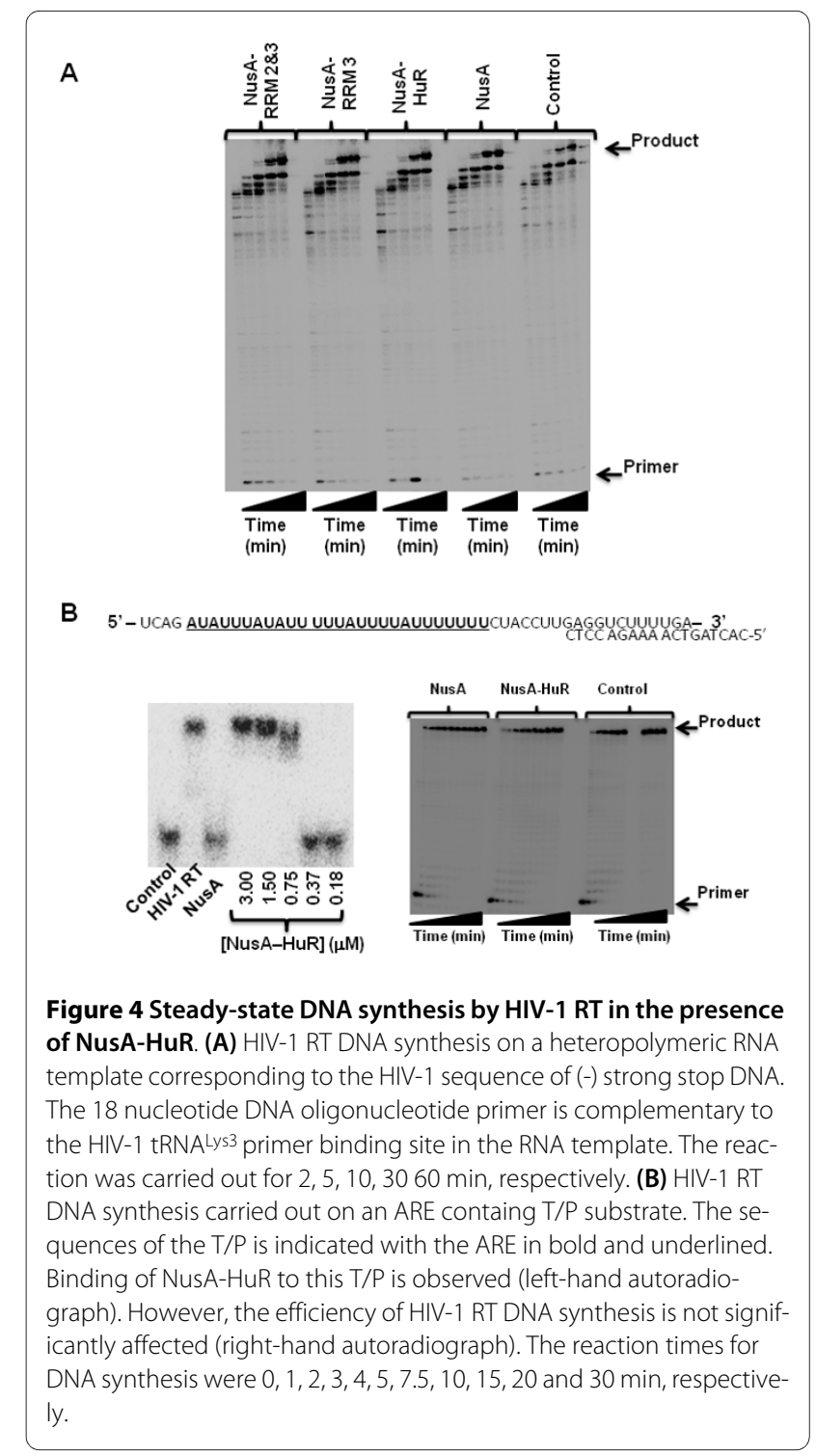

residue located between the thrombin cleavage site and $\mathrm{N}$-terminus of HuR. Although unlikely, this minor difference could contribute to differences in the relative solution stabilities of the GST-HuR constructs used in the two different studies.

Lemay et al. also reported that knockdown of HuR expression in HeLa P4.2 cells by RNA interference inhibited both the early and late steps of HIV-1 reverse transcription. While this could be caused by a direct effect of $\mathrm{HuR}$ on reverse transcription, it also could arise via indirect effects on other host cell factors that are important in HIV-1 replication. For example, it is well documented that tumor-necrosis factor-alpha (TNF- $\alpha$ ) levels in cells significantly impact HIV-1 replication [23-26] and that the expression of many inflammatory cytokines, including TNF- $\alpha$, is tightly regulated at the post-transcriptional level by HuR [27]. Interestingly, several studies have dem- 
onstrated that HuR may undergo post-translational phosphorylation at S202 and/or S242 [28,29]. Therefore, one cannot rule out the possibility that Lemay et al identified an interaction between a post-translationally modified $\mathrm{HuR}$ protein and HIV-1 RT in their yeast-two hybrid screen, and that this interaction may be of biological relevance.

In summary, the NMR chemical shift titration experiments with purified proteins, presented in this report, demonstrate unambiguously that no direct protein-protein interactions between HIV-1 RT and HuR are present in vitro up to concentrations of $\sim 200 \mu \mathrm{M}$. It should be noted that the RT used in our study is derived from an LAI isolate (group M, subtype B), whereas the RT used in the Lemay et al study was derived from a BH10 isolate (group M, subtype B). There are amino acid differences between these two isolates in their RNase $\mathrm{H}$ domains at codons 447 [N (BH10) T S (LAI)], 461 (K T R), 468 (P T T), 471 (N T D), 482 (Y T H) and 559 (V T I). However, all of these substitutions exist as polymorphisms in the RT subtype B sequences deposited in the Stanford HIV database. Furthermore, although we found no evidence for a direct protein-protein interaction between $\mathrm{HuR}$ and HIV-1 RT in this study, an indirect interaction may be mediated by RNA. However, we could not detect any influence of HuR on HIV-1 RT DNA synthesis, even on T/P substrates that contain AREs and bound both HIV-1 RT and HuR (Fig. 4B). Therefore, our results suggest that HuR does not interfere with HIV-1 replication through a direct interaction with the viral reverse transcription complex, but through indirect effects possibly mediated via unidentified host factors and/or RNA.

In the search for host-pathogen interactions, a burgeoning field in modern virology, many potential interactions have been identified for HIV-1 in the last 2 or 3 years through high through-put screens [8-10,12,30,31]. Our present follow up study using purified proteins illuminates some of the potential pitfalls associated with such approaches, and highlights the urgent need to carry out stringent biophysical validation of any putative interaction.

\section{Methods \\ Cloning}

The cDNA encoding HuR (National Center for Biotechnology Information Reference Sequence NM_001419) was purchased from Open Biosystems (Rockford, IL) and from Origene Technologies (Rockville, MD). DNA encoding full-length HuR (residues 1-326) was cloned between the EcoR1 and Xho1 restriction sites of pET43A (EMD Chemicals Inc., San Diego, CA) and between the BamH1 and EcoR1 restriction sites of pGEX-2T (GE Healthcare, Piscataway NJ). A TEV protease recognition sequence (ENLYFQS) was engineered at the C-terminus of the NusA fusion protein in pET43A. Constructs coding for both RRM 1\&2 (residues 16-186) and RRM 3 (residues 241-326) domains of HuR were cloned between the EcoRI and XhoI restriction sites of pET21a (EMD Chemicals Inc., San Diego, CA). The coding sequence for the RNase H domain of RT (residues 433-560) was amplified and cloned between EcoRI and XhoI restriction sites of pET32a (EMD Chemicals Inc., San Diego, CA) and was modified to include a TEV Protease recognition site at the C-terminus of thioredoxin [32]. The integrity of all clones was assessed by full-length sequencing of the respective plasmids.

\section{Protein expression and purification}

The HuR constructs as well as the RNase $\mathrm{H}$ domain of HIV-1 RT were expressed in E. coli Rosetta 2 (DE3), cultured in Luria-Bertani media. Protein expression was induced by the addition of $0.4 \mathrm{mM}$ IPTG, and the cells were grown at $18^{\circ} \mathrm{C}$ for 16 to $20 \mathrm{~h}$. Cells were opened using a microfluidizer (Newton, MA), and proteins were purified using $5 \mathrm{~mL} \mathrm{Ni-NTA}$ columns. Aggregated material was removed by gel-filtration column chromatography using Hi-Load Superdex200 16/60 (GE Healthcare, Piscataway, NJ) equilibrated with a buffer containing 25 $\mathrm{mM}$ sodium phosphate, $\mathrm{pH} 7.5,150 \mathrm{mM} \mathrm{NaCl}, 10 \%$ glycerol, $1 \mathrm{mM}$ DTT, and $0.02 \%$ sodium azide. NusA-HuR and NusA-RRM 3 were further purified on a Hi-Trap QP column (GE Healthcare, Piscataway, NJ) at pH 7.5 using a 0-1 M NaCl gradient. NusA-RRM 1\&2 was further purified on a Hi-Trap SP column (GE Healthcare, Piscataway, $\mathrm{NJ})$ at $\mathrm{pH} 6.5$ using a 0-1 $\mathrm{M} \mathrm{NaCl}$ gradient. The RNase $\mathrm{H}$ domain of HIV-1 RT was obtained after TEV protease digestion of the TRX fusion protein and purified on a HiTrap SP column (GE Healthcare, Piscataway, NJ) at $\mathrm{pH}$ 7.5 using a $0-1 \mathrm{M} \mathrm{NaCl}$ gradient. Buffer exchange was carried out using Amicon concentrators (Millipore, Billerica, MA), and proteins were stored at $4^{\circ} \mathrm{C}$ in solution. GST-HuR and HIV-1 RT were purified as described previously $[9,33,34]$. For isotopic labeling, proteins were expressed as described above in modified minimal media using ${ }^{15} \mathrm{NH}_{4} \mathrm{Cl}$ as the sole nitrogen source. The [15N]labeled HuR RRM 3 and HuR RRM 1\&2 used in NMR experiments contained extra amino acids (LEHHHHHH) at their C-termini, while the [15N]-labeled HIV-1 RT RNase $\mathrm{H}$ domain NMR sample contained two additional amino acids (EF) at its $\mathrm{N}$-terminus.

\section{Multi-angle light scattering}

Light-scattering data were obtained using an analytical Superdex-200 column $(1 \mathrm{~cm} \times 30 \mathrm{~cm})$ with in-line multiangle light-scattering (DAWN HELEOS, Wyatt Technology, Inc., Santa Barbara, CA) and refractive index detectors (OPTILAB DSP, Wyatt Technology, Inc.). Proteins were applied to the pre-equilibrated column at a flow- 
rate of $0.5 \mathrm{ml} / \mathrm{min}$ at room temperature and eluted with $25 \mathrm{mM}$ sodium phosphate buffer, $\mathrm{pH} 7.5$, containing 150 $\mathrm{mM} \mathrm{NaCl}, 10 \mathrm{mM} \beta$-mercaptoethanol, $0.02 \%$ sodium azide and $5 \%$ glycerol. Total protein amounts loaded were $100 \mu \mathrm{L}$ of $7.8 \mathrm{mg} / \mathrm{mL}$ NusA-RRM 3 and $100 \mu \mathrm{L}$ of $1.1 \mathrm{mg} /$ mL NusA-HuR.

\section{NMR spectroscopy}

For the NMR experiments, 30-200 $\mu \mathrm{M}$ uniformly- [15N]labeled protein samples without and with equimolar or two-fold molar amounts of the proposed binding partner were prepared using the identical buffer $(25 \mathrm{mM}$ sodium phosphate buffer, $\mathrm{pH} 7.5$, containing $150 \mathrm{mM} \mathrm{NaCl}, 10$ $\mathrm{mM} \beta$-mercaptoethanol, $0.02 \%$ sodium azide, $5 \%$ glycerol and $7 \%{ }^{2} \mathrm{H}_{2} \mathrm{O}$ ). All ${ }^{1} \mathrm{H},{ }^{15} \mathrm{~N}-\mathrm{HSQC}$ NMR experiments [16] were performed at $17^{\circ} \mathrm{C}$ on a Bruker Avance $600 \mathrm{MHz}$ spectrometer, equipped with a $5 \mathrm{~mm}$ triple resonance and $\mathrm{z}$-axis gradient cryoprobe.

\section{Gel Mobility Shift Assays}

Gel mobility shift assays were used to evaluate the binding interaction between HuR and RNA. In these assays, the amount of RNA-bound HuR present in solution is assessed by native gel electrophoresis. $\mathrm{HuR}(0-3 \mu \mathrm{M}$ total $)$ was equilibrated with $100 \mathrm{nM}$ of ${ }^{32} \mathrm{P}$-labeled RNA for $1 \mathrm{hr}$ in $50 \mathrm{mM}$ Tris $\mathrm{pH} 7.5,50 \mathrm{mM} \mathrm{KCl}$ at $37^{\circ} \mathrm{C}$. Samples were then loaded on a $7 \%$ polyacrylamide gel in $40 \mathrm{mM}$ Trisacetate, $\mathrm{pH}$ 8.0, containing $1 \mathrm{mM}$ EDTA. Gels were run at room temperature for $30 \mathrm{~min}$ (100 V constant voltage), and radioactivity was quantified using a Bio-Rad GS525 Molecular Imager (Bio-Rad Laboratories, Inc., Hercules, CA).

\section{HIV-1 RT DNA synthesis reactions}

The heteropolymeric RNA-dependent DNA polymerase T/P corresponding to the HIV-1 sequence used for (-) strong stop DNA synthesis was prepared as described previously [21,22]. The 18 nucleotide DNA oligonucleotide primer used in this experiment is complementary to the HIV-1 tRNA ${ }^{\mathrm{Lys} 3}$ primer binding site and was 5 '-end radiolabelled with $\gamma$ - [32P]-ATP prior to annealing to the RNA template. DNA polymerization reactions were carried out by incubating $50 \mathrm{nM} \mathrm{HIV-1}$ RT with $3 \mu \mathrm{M}$ NusA$\mathrm{HuR}$ in $50 \mathrm{mM}$ Tris- $\mathrm{HCl}(\mathrm{pH} 8.0), 50 \mathrm{mM} \mathrm{KCl}$ for $5 \mathrm{~min}$ before the addition of $20 \mathrm{nM}$ T/P, containing $1 \mu \mathrm{M}$ dNTP and $10 \mathrm{mM} \mathrm{MgCl}_{2}$. After defined incubation periods, aliquots were removed and the reaction was quenched with equal volumes of gel loading dye. Products were separated by denaturing gel electrophoresis and radioactivity was quantified with a Bio-Rad GS525 Molecular Imager.

\section{Competing interests}

The authors declare that they have no competing interests.

\section{Authors' contributions}

Conceived and designed the experiments: JA, IJLB, AMG and NSC. Performed the experiments: JA, IJLB, SD, KH and JC. Analyzed the data: JA, IJLB, AMG and NSC. Wrote the paper: JA, IJLB, AMG and NSC.

\section{Acknowledgements}

We thank Dr. Rieko Ishima for useful discussions about RNaseH and Mike Delk for NMR technical support. This work is a contribution from the Pittsburgh Center for HIV Protein Interactions and was supported by the National Institutes of Health Grant (GM082251).

\section{Author Details}

1Department of Structural Biology, Division of Infectious Diseases, University of Pittsburgh School of Medicine, Pittsburgh, PA 15261, USA and 2Department of Medicine, Division of Infectious Diseases, University of Pittsburgh School of Medicine, Pittsburgh, PA 15261, USA

Received: 22 February 2010 Accepted: 7 May 2010

Published: 7 May 2010

\section{References}

1. Aiken C, Trono D: Nef stimulates human immunodeficiency virus type 1 proviral DNA synthesis. J Virol 1995, 69:5048-5056.

2. Goncalves J, Korin Y, Zack J, Gabuzda D: Role of Vif in human immunodeficiency virus type 1 reverse transcription. J Virol 1996, 70:8701-8709.

3. Harrich D, Ulich C, García-Martínez LF, Gaynor RB: Tat is required for efficient HIV-1 reverse transcription. EMBO J 1997, 16:1224-1235.

4. Kiernan RE, Ono A, Englund G, Freed EO: Role of matrix in an early postentry step in the human immunodeficiency virus type 1 life cycle. J Virol 1998, 72:4116-4126.

5. Wu X, Liu H, Xiao H, Conway JA, Hehl E, Kalpana GV, Prasad V, Kappes JC: Human immunodeficiency virus type 1 integrase protein promotes reverse transcription through specific interactions with the nucleoprotein reverse transcription complex. J Virol 1999, 73:2126-2135.

6. Weiss S, König B, Morikawa Y, Jones I: Recombinant HIV-1 nucleocapsid protein $\mathrm{p} 15$ produced as a fusion protein with glutathione $\mathrm{S}$ transferase in Escherichia coli mediates dimerization and enhances reverse transcription of retroviral RNA. Gene 1992, 121:203-212.

7. Kohlstaedt LA, Wang J, Friedman JM, Rice PA, Steitz TA: Crystal structure at 3.5 A resolution of HIV-1 reverse transcriptase complexed with an inhibitor. Science 1992, 256:1783-1790.

8. König R, Zhou Y, Elleder D, Diamond TL, Bonamy GM, Irelan JT, Chiang CY, Tu BP, De Jesus PD, Lilley CE, Seidel S, Opaluch AM, Caldwell JS, Weitzman MD, Kuhen KL, Bandyopadhyay S, Ideker T, Orth AP, Miraglia LJ, Bushman FD, Young JA, Chanda SK: Global analysis of host-pathogen interactions that regulate early-stage HIV-1 replication. Cell 2008, 135:49-60.

9. Lemay J, Maidou-Peindara P, Bader T, Ennifar E, Rain JC, Benarous R, Liu LX: HuR interacts with human immunodeficiency virus type 1 reverse transcriptase, and modulates reverse transcription in infected cells. Retrovirology 2008, 5:47-61.

10. Lemay J, Maidou-Peindara P, Cancio R, Ennifar E, Coadou G, Maga G, Rain JC, Benarous R, Liu LX: AKAP149 binds to HIV-1 reverse transcriptase and is involved in the reverse transcription. J Mol Biol 2008, 383:783-796.

11. Warrilow D, Meredith L, Davis A, Burrell C, Li P, Harrich D: Cell factors stimulate human immunodeficiency virus type 1 reverse transcription in vitro. J Virol 2008, 82:1425-1437.

12. Tabah A, Tardiff K, Mansky L: Characterization of a novel TRIM protein that possesses anti-HIV-1 activity [abstract]. 16th Conference on Retroviruses and Opportunistic Infections, February 8-11, 2009. Montreal, Canada.

13. Liu J, Dalmau J, Szabo A, Rosenfeld M, Huber J, Furneaux H: Paraneoplastic encephalomyelitis antigens bind to the AU-rich elements of mRNA. Neurology 1995, 45:544-550.

14. Ma WJ, Cheng S, Campbell C, Wright A, Furneaux H: Cloning and characterization of HuR, a ubiquitously expressed Elav-like protein. J Biol Chem 1996, 271:8144-8151. 
15. Meisner NC, Hackermüller J, UhI V, Aszódi A, Jaritz M, Auer M: mRNA openers and closers: modulating AU-rich element-controlled mRNA stability by a molecular switch in mRNA secondary structure. Chembiochem 2004, 5:1432-1447.

16. López de Silanes I, Zhan M, Lal A, Yang X, Gorospe M: Identification of a target RNA motif for RNA-binding protein HuR. Proc Natl Acad Sci USA 2004, 101:2987-2992

17. Fialcowitz-White EJ, Brewer BY, Ballin JD, Willis CD, Toth EA, Wilson GM: Specific protein domains mediate cooperative assembly of HuR oligomers on AU-rich mRNA-destabilizing sequences. J Biol Chem 2007, 282:20948-20959.

18. Meisner NC, Hintersteiner M, Mueller K, Bauer R, Seifert JM, Naegeli HU, Ottl J, Oberer L, Guenat C, Moss S, Harrer N, Woisetschlaeger M, Buehler C, Uhl V, Auer M: Identification and mechanistic characterization of lowmolecular-weight inhibitors for HuR. Nat Chem Biol 2007, 3:508-515.

19. Bodenhausen G, Ruben DJ: Natural abundance nitrogen-15 NMR by enhanced hetero-nuclear spectroscopy. Chem Phys Lett 1980, 69:185-189.

20. Mori S, Abeygunawardana C, Johnson MO, Vanzijl PCM: Improved Sensitivity of HSQC Spectra of Exchanging Protons at Short Interscan Delays Using a New Fast HSQC (FHSQC) Detection Scheme That Avoids Water Saturation. J Magn Reson Series B 1995, 108:194-98.

21. Brehm JH, Mellors JW, Sluis-Cremer N: Mechanism by which a glutamine to leucine substitution at residue 509 in the ribonuclease $\mathrm{H}$ domain of HIV-1 reverse transcriptase confers zidovudine resistance. Biochemistry 2008, 47:14020-14027.

22. Sluis-Cremer N, Arion D, Parikh U, Koontz D, Schinazi RF, Mellors JW, Parniak MA: The 3'-azido group is not the primary determinant of 3'azido-3'-deoxythymidine (AZT) responsible for the excision phenotype of AZT-resistant HIV-1. J Biol Chem 2005, 280:29047-29052.

23. Michihiko S, Yamamoto N, Shinozaki F, Shimada K, Soma G, Kobayashi N: Augmentation of in-vitro HIV replication in peripheral blood mononuclear cells of AIDS and ARC patients by tumor necrosis factor. Lancet 1989, 27:1206-1207.

24. Mellors JW, Griffith BP, Ortiz MA, Landry ML, Ryan JL: Tumor necrosis factor-alpha/cachectin enhances human immunodeficiency virus type 1 replication in primary macrophages. J Infect Dis 1991, 163:78-82.

25. Li Q, Gebhard K, Schacker T, Henry K, Haase AT: The relationship between tumor necrosis factor and human immunodeficiency virus gene expression in lymphoid tissue. J Virol 1997, 71:7080-7082.

26. Lane BR, Markovitz DM, Woodford NL, Rochford R, Strieter RM, Coffey MJ: TNF-alpha inhibits HIV-1 replication in peripheral blood monocytes and alveolar macrophages by inducing the production of RANTES and decreasing C-C chemokine receptor 5 (CCR5) expression. J Immunol 1999, 163:3653-3661.

27. Seko Y, Cole S, Kasprzak W, Shapiro BA, Ragheb JA: The role of cytokine mRNA stability in the pathogenesis of autoimmune disease. Autoimmun Rev 2006, 5:299-305.

28. Kim HH, Yang X, Kuwano Y, Gorospe M: Modification at HuR(S242) alters HuR localization and proliferative influence. Cell Cycle 2008, 7:3371-3377.

29. Kim HH, Abdelmohsen K, Lal A, Pullmann R Jr, Yang X, Galban S, Srikantan S, Martindale JL, Blethrow J, Shokat KM, Gorospe M: Nuclear HuR accumulation through phosphorylation by Cdk1. Genes Dev 2008, 22:1804-1815

30. Brass AL, Dykxhoorn DM, Benita Y, Yan N, Engelman A, Xavier RJ, Lieberman J, Elledge SJ: Identification of host proteins required for HIV infection through a functional genomic screen. Science 2008, 319:921-926.

31. Zhou H, Xu M, Huang Q, Gates AT, Zhang XD, Castle JC, Stec E, Ferrer M, Strulovici B, Hazuda DJ, Espeseth AS: Genome-scale RNAi screen for host factors required for HIV replication. Cell Host Microbe 2008, 4:495-504.

32. Ahn J, Byeon IJ, Byeon CH, Gronenborn AM: Insight into the structural basis of pro- and antiapoptotic p53 modulation by ASPP proteins. J Biol Chem 2009, 284:13812-13822.

33. Le Grice SF, Cameron CE, Benkovic SJ: Purification and characterization of human immunodeficiency virus type 1 reverse transcriptase. Methods Enzymol 1995, 262:130-144.

34. Le Grice SF, Gruninger-Leitch F: Rapid purification of homodimer and heterodimer HIV-1 reverse transcriptase by metal chelate affinity chromatography. Eur J Biochem 1990, 187:307-314. doi: $10.1186 / 1742-4690-7-40$

Cite this article as: Ahn et al., The RNA binding protein HuR does not interact directly with HIV-1 reverse transcriptase and does not affect reverse transcription in vitro Retrovirology 2010, 7:40

\section{Submit your next manuscript to BioMed Central and take full advantage of:}

- Convenient online submission

- Thorough peer review

- No space constraints or color figure charges

- Immediate publication on acceptance

- Inclusion in PubMed, CAS, Scopus and Google Scholar

- Research which is freely available for redistribution

Submit your manuscript at www.biomedcentral.com/submit
C BioMed Central 